\title{
„Azon orvosságok kezdete, melyeket a májra adnak"
}

\author{
Katona Júlia ${ }^{1}$ - Győry Hedvig dr. ${ }^{2}$ - Blázovics Anna dr. ${ }^{1}$ \\ ${ }^{1}$ Semmelweis Egyetem, Gyógyszerésztudományi Kar, Farmakognóziai Intézet, Budapest \\ ${ }^{2}$ Szépmúvészeti Múzeum, Budapest
}

\begin{abstract}
Rövidítések
AIDS = acquired immune deficiency syndrome; ALT = alaninaminotranszferáz; AST = aszpartát-aminotranszferáz; CAT = kataláz; $\mathrm{CCl}_{4}=$ szén-tetraklorid; CYP $1 \mathrm{Al} / 2$ = citokróm P450 családba tartozó CYP 1Al és CYP lA2 izoenzimek; DPPH = 1,1-difenil-2-pikrilhidrazil; EAC $=$ Ehrlich ascites carcinoma sejtvonal; GC/MS = (gas chromatography/mass spectrometry) gázkromatográfia/tömegspektrometria; GSH-peroxidáz = glutation-peroxidáz; HCN = hidrogén-cianid; HCT 116 = humán colorectalis adenocarcinoma sejtvonal; $\mathrm{HCV}=$ hepatitis C-vírus; HDL = high-density lipoprotein; HEPG-2 = hepatoblastoma G2 sejtvonal; LDL = low-density lipoprotein; MCF-7 = Michigan Cancer Foundation-7 emlőráksejtvonal; MDA = malondialdehid; $\mathrm{NMR}=$ (nuclear magnetic resonance $)$ mágneses magrezonancia; $\mathrm{NO}=$ nitrogén-monoxid; NSAID $=($ nonsteroidal anti-inflammatory drug) nem szteroid gyulladáscsökkentő; Ph. Hg. VIII. = (Pharmacopoea Hungarica VIII. $)$ Magyar Gyógyszerkönyv VIII. kiadása; RP-LC = (reversed phase liquid chromatography) fordított fázisú folyadékkromatográfia; $S$. mansoni $=$ Schistosoma mansoni TNF- $\alpha=$ tumornekrózis-faktor- $\alpha$
\end{abstract}

Az óegyiptomi kórképek kutatása a térségben ma is elöforduló betegségek jobb megismerését segíti. A hazánkban is egyre inkább érződő globális felmelegedés pedig a trópusi/szubtrópusi betegségek kutatását, illetve azok kialakulásának és elterjedésének a megakadályozását teszik egyre sürgetőbbé, mivel azok a világ számos pontján jelentkezhetnek $[1,2]$. A hepatitis C-vírus-fertőzést tekintve ma Egyiptom számít az egyik legfertőzöttebb országnak a kedvezőtlen egészségügyi és higiénés viszonyok miatt. A fertőzések között viszont jelentősen sikerült visszaszorítani a múmiákon is jól kimutatható vérmételyt (Schistosoma haematobium és $S$. mansoni), de ismert, hogy még 1963-ban az ország lakosságának fele e kórokozóktól szenvedett [3-5].

$\mathrm{Az}$ ókori társadalom életminősége lényegesen roszszabb volt a mainál. A korabeli életszínvonal mellett azonban a súlyos fertőzések és balesetek is nagyban hozzájárultak a korai elhalálozáshoz, pedig az óegyiptomiak kimagaslóan odafigyeltek környezetük tisztaságára és a személyes higiénére. Az étkezések alkalmával használt bronzedények tisztán tartására például fokozottan ügyeltek. Helytelenítették, ha valaki étkezés előtt nem mosta meg a kezét - az előkelő lakomákon a fogások között is szokás volt a kézmosás. Ezek a szokások valamelyest korlátot szabhattak a gyakori hepatitis A-vírus terjedésének is. Az óegyiptomi társadalom maximális átlagéletkora a fáraókor 3000 éve alatt változott, de átlagban a 30-40 évet nem haladta meg [6]. Összehasonlításképpen, a 2015-ös demográfiai mutatók alapján az egyiptomi férfiak várható élettartama 69, míg a nőké hozzávetőlegesen 73 év [7].

$\mathrm{Az}$ átlagegyiptomiak étkezésére nem volt jellemző a zsírokban gazdag étrend, bár az elit esetében nagy menynyiségü telített zsírsavakkal lehet számolni [8]. A kövérség a jólét jele volt, az előkelők sírjaiban erre találni utalásokat. A népesség körében kialakult zsírmáj oka azonban valószínüsíthetően nem a táplálkozási eredetű obesitas volt. Sokkal valószínúbb, hogy a fertőzések és a jelentős mennyiségű alkoholtartalmú italok fogyasztása játszhatott kiemelkedő szerepet az ókori egyiptomi társadalmat érintő májbetegségek létrejöttében. A természetes vizek kórokozókkal szennyezett volta bizonyára közrejátszott abban, hogy gyakran itták a növényekből készült, erjesztett italokat. A sör, később a bor fogyasztása is a mindennapi élet részét képezte, de voltak más erjesztett italaik is, bár ezeknek jobbára csak a nevét ismerjük, közkedveltségük mértékét nem. A különböző sörfajták és a bor ugyancsak alapvetően fontosak voltak a különféle vallási rituálékban, de a betegségek gyógyítására szánt orvosi receptek is számos helyen hasznosítják jótékony hatásukat. A túlzott alkoholfogyasztás sok esetben részegséghez vezetett (1. ábra), amit bizonyos alkalmakkor rituális okokból kifejezetten kívánatosnak tekintettek, mint például Hathor részegségi ünnepén. (A mitológia szerint Hathor istennő, a Nap leánya oroszlán alakot öltve megbüntette az atyját kigúnyoló embereket, de megrészegedve a vértől nem hagyta abba az öldöklést. Az istenek ezért cselhez folyamodtak, és vörösre festett sörrel hatalmas tócsát készítettek. A vérszomjas oroszlán ettől eszméletvesztésig lerészegedett, és amikor kijózanodott, akkor fogta csak fel a történte- 


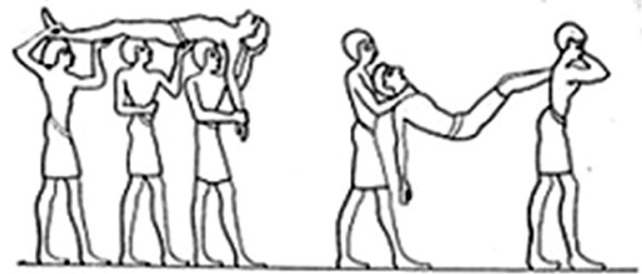

1. ábra

Bortól megrészegült emberek hazaszállítása az ünnepről (Food Gift of Osiris, Beni Hassan Redrawn from Wilkinson, 1878 Vol.1, Fig. 160)

ket. Egy másik mítoszban a Núbiából hazatérő istennő tiszteletére nagy ünnepségeket rendeztek, ahol az öröm, ünneplés részeként sokan lerészegedtek. Az istennőnek számos ünnepe volt, ezek között szerepel a „részegség ünnepe", amikor ezekről az eseményekről emlékeztek meg. Ilyenkor az ünneplők kellő mennyiségü bor fogyasztásával kívánták az isteni állapotot átélni, így kerülni az istennő közelébe.) Ezért gyakoriak lehettek a májbetegség különböző stádiumai [6].

Tudjuk, hogy a májat az emberi test elengedhetetlenül fontos szervének tartották, hiszen a kanopusz edényekben mumifikálva őrizték meg a túlvilági léthez, és azt az egyik Hórusz-fiú védelmére bízták, akit Imszet/Amszet néven ismerünk. Talán nem véletlenül, egybecseng vele a máj óegyiptomi neve, a miszet. Szintén a máj fontosságát jelzi, hogy Ozirisz, a halottak istene igényt tartott rá [9-12]. (A mumifikálás során a belső szervek egy részét a testből kiemelték, majd a testtel együtt „nátronsóval” azt is kiszárították, és tartósítva, pólyába tekerve a sírban a halott mellett helyezték el négy, erre a célra készített úgynevezett kanopusz edényben.)

Az ókori egyiptomiak emberi májról alkotott anatómiai ismereteit a 18. dinasztia korában lejegyzett Ebers-papirusz őrizte meg számunkra. Az úgynevezett 1. anatómiai traktátusában (Eb854-855) [13], amelyben a test felépítésének ismertetése a korabeli orvosok elméleti képzését szolgálta, a következőképpen határozták meg: „Négy ere/csatornája (mtw) van a májnak. Ezek azok, amik vizet és levegöt adnak neki. Azután ezek azok, amelyek létrehozzák az összes szenvedését ( $x A j . t)$, amikor vérrel nedvesitik be." Minthogy ebben a traktátusban valamenynyi mtw a szívből indul, feltehetően ereket jelentenek, amelyekben elképzelésük szerint egészséges embernél levegő és víz áramlott. Tudjuk azonban, hogy az egyébként normálisnak tekintett víz is okozhatott gondot, amikor „gonosz” volt, ahogy egy 21. dinasztiabeli orákulumot tartalmazó papiruszból kiderül [14]. Kóros állapotnak azonban elsősorban nem a vizes állapotot tekintették, hanem a vér jelenlétét, amely „benedvesítette”. Mivel nedvesség hatására a testek térfogata megnő, feltehetően a fent idézett esetben is megnagyobbodásra utalnak, ami a páciens esetében fizikai szenvedést okozott [15].

Kifejezetten a máj kezelésére szolgáló receptek azonban csak az Ebers-papiruszon maradtak fenn: egy a ,szinszája” (sokszor gyomornak fordítják) könyvében, ahol a datolyamagot és a nem azonosított pah-szerit növényt használják (Ebl88), és később 5 recept egy csoportban (Eb477-481). Itt az első recept bevezető sora: „Azon orvosságok kezdete, melyeket a májra adnak”, arra mutat, hogy mind az öt recept valamikor egy önálló könyvet alkotott, feltehetően további receptekkel együtt. A betegség tüneteit nem írják le, de kezelésük valamennyi esetben belsóleg történt, és négy napon keresztül kellett ugyanazt az orvosságot bevenni (swj r hrw 4). Készítésük is azonos módon történt: miután a hozzávalókat öszszekeverték, éjszakára a harmatnak kitették, és reggel leszürték (sDr r jAd.t, atH).

A hieratikus írással lemásolt szövegben folyamatosan írtak. A címet és a mennyiségeket piros tintával emelték ki. Ez a forma a gyújteményes könyv létrejöttének egy időszámításunkhoz közelebbi időszakára mutat, ahogy a törtekkel megadott mennyiségek is erre utalnak. A források hézagos volta miatt azonban nem tudjuk, hogy ez hány száz évet jelent. A tört mennyiségeknek az udzsat szem részeivel történő megadása viszont már a gyógyító mágia világába vezet, ami bizonyosan befolyásolta a kezelésre szánt anyagok kiválasztását is [16], de a jelen munkában az egyiptomi orvoslásnak ettől az aspektusától eltekintünk (2. ábra).

A receptek összetételében jelentős eltérések figyelhetôk meg, amelyeknek okát nem ismerjük. Elképzelhető, hogy a forrásul szolgáló máj könyvét eredetileg különböző helyekről összegyưjtött receptekből hozták létre, amik más-más iskolákból származtak - erre utal, hogy ugyan a készítés és felhasználás módja valamennyinél teljesen megegyezik, mégis csak egy esetben írták a mjt.t („ugyanúgy”) szót, a többinél a teljes protokollt lejegyezték [17]. Ezt a feltételezést látszik alátámasztani, hogy a receptekben szereplő anyaglisták erősen eltérnek egymástól. Azonban éppen ennek alapján merül fel az a lehetőség is, hogy a máj különböző elváltozásait kezelték velük, és az orvosság kiválasztását az orvos saját tapasztalata alapján végezte el.

Az itt felhasznált materia medica két ásvány kivételével (stj/sárga okker, sjA/valamilyen ásvány) kizárólag növényi eredetú, amelyek más összetételben további re-

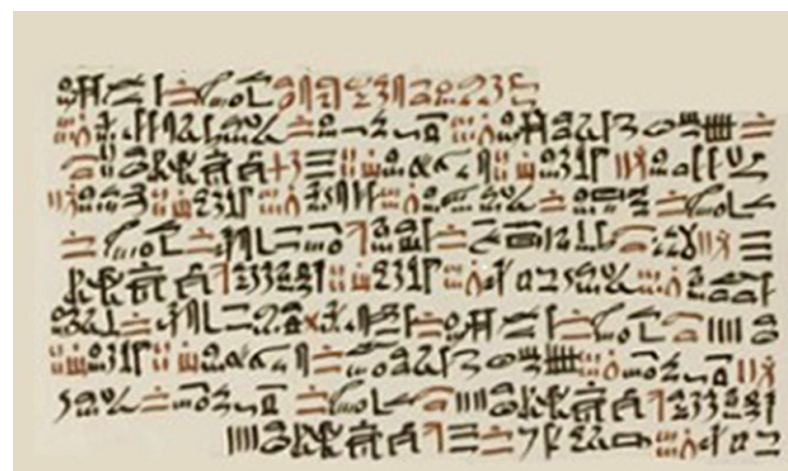

2. ábra Az Ebers-papirusz 67, 7-16. sorai a máj orvosságainak a leírásá val (Ebers, 1875, Bd. I., 67. tábla) 
ceptek alkotórészeit is képezik [18]. A következő lista állítható össze: pAy.t/akácia mézga, jns.t/ánizs, wan/ boróka, xAsy.t/földitök, dAb/füge, nbs/krisztustövis, sSn/lótusz, wnSj/mazsola, jsw/nád, Snj-tA/papirusztermés(?), jSd/sivatagi szilva, DAr.t/szentjánoskenyér, nqAw.t/érett szikomor, jArr.t/szőlő, snTr/tömjén, sm.t/zsázsa, és folyadékok, mint a jrp/bor, jrT.t/tej, Hnq.t/sör és mw/víz.

A felsorolás erősen emlékeztet a Chester Beatty-papirusz igen töredékes 31-32 és 37-41 receptjeinek anyagneveire, amik szintén hasonló mennyiségekkel szerepelnek. A felsorolt anyagok alapján felmerül annak a lehetősége, hogy azok is a májra vonatkoznak - ez akkor lenne bizonyos, ha a szövegben keletkezett hiányzó részen eredetileg a „jobb” szó állna $(/ / / / \mathrm{m}$ Drww / "/// oldalban”).

$\mathrm{Az}$ orvosi receptekben szereplő komponensek hatóanyagai egymást kiegészítve járultak hozzá a májbetegségek kezeléséhez. Hatóanyagaikat áttekintve a flavonoidok, fenoloidok, szaponinok és illóolajok túlsúlya jellemzi őket.

\section{Flavonoidok}

A flavonoidok szinte az összes említett drog meghatározó alkotóelemei, amelyek többek között csökkentik a vér koleszterinszintjét, májvédő, gyulladásellenes és antioxidáns tulajdonságokkal rendelkeznek. Ezen belül az antocianinoknak, az újabb kutatások szerint, már rákellenes tulajdonságait is igazolták.

Az ókori egyiptomiak gyakran használtak különféle ásványokból készült festékeket esztétikai célra. Az alkalmazott ásványok egyike a galenit, amely számos nehézfémet tartalmaz, például ólmot és kadmiumot. Mivel a kadmium legfőképpen a májban és a vesében akkumulálódik, ezért fontos szemügyre venni a receptekben szereplő Acacia nilotica L., nílusi akácia (Mimosaceae) pozitív hatásait a kadmiummérgezés tüneteinek enyhítésében. A nílusi akáciában található egyes flavonoidok (kromonszármazékok) képesek arra, hogy két vagy három vegyértékü fémionokkal $\left(\mathrm{Cd}^{2+}\right)$ fémkomplexet képezzenek, így mérsékeljék az akkumulálódott fémek szabadgyökös reakcióit [19]. Ez a jelenség is indokolja, hogy az akácia helyet kapjon a májjal kapcsolatos receptekben. A növény az Eb477-ben található meg.

\section{$\operatorname{Eb477~(67,7-9)}$}

Azon orvosságok kezdete, melyeket a májra adnak: füge $1 / 8$, sivatagi szilva termése $1 / 8$, szölöszem $1 / 16$, felhasitott szikomorfüge $1 / 8$, földitök termése $1 / 16$, akáciamézga 1/32, tömjén 1/64, zsázsa 1/64, víz 15 ro (1 ro $14 \mathrm{ml})$, éjjel a harmatnak kitenni, áttörni, négy napig inni.

(HAt-a pXr.t rdj s Hr mjs.t: dAb $1 / 8$, jSd 1/8, Ssp.t n.t jAr.t $1 / 64$, nqaw.t $1 / 8$, pr.t xAsy.t $1 / 64$, pAy.t $1 / 32$, snTr $1 / 64$, sm.t 1/64, mw 15, sDr r jAd.t, atH, swj r hrw 4.)
A recept első hozzávalója a Ficus carica L. (közönséges füge), a Moraceae családba tartózó Ficus genusok egyike. A füge eredeti hazája Kis-Ázsia, Szíria és Izrael, de már az ókorban is igen elterjedt volt a dél-európai mediterrán vidéken is. A szubtrópusi Észak-Afrikában szintén előszeretettel termesztették. A növényi drog elsősorban a fügefa zöld vagy érett termése, levele, fiatal hajtása, kérge és a gyümölcsben található gyanta. A növény teljes flavonoid-, antocianinprofiljának meghatározását fordított fázisú folyadékkromatográfiával (RP-LC) végezték, és az eredmények alapján a cianidin bizonyult a legfőbb aglikonnak. NMR-vizsgálatok alapján pedig bebizonyosodott, hogy a fügefa gyümölcsében a legjelentősebb antocianin a cianidin-3-O-rutinozid [20-22].

A mediterrán területeken a különböző kultúrák frissen vagy szárítva, élelmiszerként („a szegények eledele”) vagy a gyógyászat értékes részeként külsóleg és belsőleg használták/használják a mai napig többek között láz, székrekedés és kézremegés kezelésére. Jelenleg ismert vércukorszint-csökkentő, valamint pektintartalma miatt trigliceridszint- és koleszterinszint-csökkentő hatása. A füge tejnedvében található ficin enzim felel a növény féreghajtó hatásáért, főként ascariasis és trichuriasis esetén. A gyümölcsökből készült főzet emésztést segítő, enyhén laxatív, amelyet gyermekek esetében is bátran alkalmazhattak [21-23].

Egy tanulmány, amely a füge májra gyakorolt hatását vizsgálta állatkísérletekben, azt a következtetést vonta le, hogy a metanolmérgezéssel előidézett májat érintő oxidatív károsodás megelőzésében a füge kulcsfontosságú szerepet tölt be. Az eredmények azt mutatták, hogy a fügét fogyasztó metanollal itatott patkányok májának ALT (alanin-aminotranszferáz) és AST (aszpartát-aminotranszferáz) enzimaktivitása nagymértékben javult és a hepatotoxicitas mértéke csökkent [24].

A közönséges fügéhez igen hasonlít az eperfafélék (Moraceae) családjába tartozó szikomorfüge (Ficus sycomorus L.), amely szintén szerepel a fenti receptben. Afrika és a mediterrán területek egyik legelterjedtebb növénye. Az ókori egyiptomiak az istenek fájának tekintették és nagy tisztelet övezte. A korai gyógyszerészet és orvostudomány a szikomorfüge gyümölcsét különféle érési stádiumokban használta fel. A májbetegségek kezeléséhez használt „felhasított” szikomorfüge a gyümölcs érettségére utal, ugyanis az érési folyamat részét képezi a bevágás, amelynek hatására az érés nagymértékben felgyorsul. Az érett gyümölcsben található vegyületek (gallotannin, szaponin, redukáló cukrok, alkaloidok, flavonoidok, antrakinonok) kedvező hatással lehetnek a májat érintő gombás fertőzések által kiváltott szövődmények leküzdésében. Az Aspergillus niger-fertőzés gyakori lehetett már az ókorban is. A mikotoxinok, az aflatoxinok, ochratoxin A, fumonisin B2 májrákot okoznak. Ez indokolhatja, hogy Afrika egyes területein a hagyományos gyógyászat manapság is elsősorban a szikomorfüge szárából és kérgéből készült kivonatot használja [25]. 
Négy receptben található meg a Vitaceae családhoz tartozó szőlő ( Vitis vinifera L.), gyümölcs, mazsola vagy bor formájában. A fáraók Egyiptomában a vörös szőlő volt általánosan elterjedt, amelyből az óegyiptomiak az általuk igen kedvelt bort is készítették. A szőlő gazdag flavonoidokban, fenolokban, antocianinokban, proantocianidinekben, szénhidrátokban, aminosavakban és ásványi anyagokban. Az utóbbi évek kutatásai alapján az egyik legkiemelkedőbb szerepet a jelentős antioxidáns tulajdonságú stilbenoidszármazék polifenol-transzrezveratrolnak tulajdonítják, amely nemcsak a friss gyümölcsben, hanem a borban is meghatározó komponens. Természetesen a vörösbor mint jótékony hatású vivőanyag is szerepelt. A szőlő a tradicionális medicinában laxatívum, sztomachikum és diuretikum. Biliaris dyspepsiában, haemorrhagiában, dysuriában és krónikus bronchitisben, valamint szívelégtelenségben és köszvény kezelésében jelenleg is használatos. Az érett gyümölcs vagy a mazsola a szubakut lép- és májmegnagyobbodás kezelésében bizonyult hatásosnak [26].

Eb480 (67,13-15)

Másik: füge $1 / 8$, sivatagi szilva termése $1 / 8$, ánizs $1 / 4$, krisztustövis kenyér $1 / 8$, szentjánoskenyér $1 / 32$, felhasitott szikomorfüge 1/16, szölöszem 1/8, zsázsa 1/64, tömjén 1/64, édes sör 20 ro, éjjel a harmatnak kitenni, összetörni és négy napig inni.

(K.t: dAb $1 / 8$, jSd $1 / 8$, jns.t $1 / 4$, dqw n nbs $1 / 8$, DAr.t $1 / 32$, nqAw.t $1 / 16$, Ssp.t n.t jAr.t $1 / 8$, sm.t 1/64, sn Tr 1/64, Hnq.t nDm.t 20, sDr n jAd.t, atx, swj r hrw 4.)

A Ceratonia siliqua L. (Fabaceae), a szentjánoskenyér, csak a fenti (Eb480) májpanaszok kezelésére szánt óegyiptomi orvosi receptben szerepel. In vitro bizonyítékok támasztják alá citosztatikus tulajdonságát. A levelek polifenolokban és flavonoidokban gazdagok, alkoholos kivonatuknak a DPPH- (1,1-difenil-2-pikrilhidrazil-) gyök megkötésének mérésén alapuló antioxidáns-kapacitás vizsgálata arra enged következtetni, hogy jelentős an-

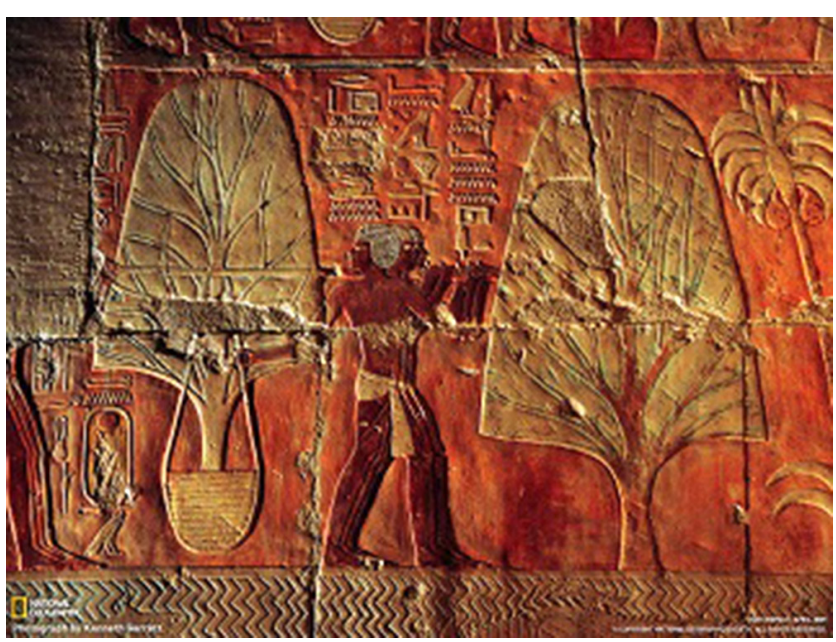

3. ábra $\mid$ Facsemete-szállítást ábrázoló dombormű Hatsepszut templomának a falán, Deir el-Bahariban tioxidáns hatással bír [27]. Kísérletesen bizonyították, hogy a benne található flavonoidok (kvercetin, apigenin, naringin és rutin) csersavval kiegészülve jelentős hepatoprotektív hatást fejthetnek ki [28]. A receptben a szentjánoskenyér édes sör mellett szerepel mint májvédő komponens. A sör azon kívül, hogy megfelelő vivőanyag, igen jelentős pozitív terápiás hatással rendelkezik. Az árpából készült sör, optimális mennyiségben fogyasztva, kedvező élettani hatásokat mutat. Az édes sör datolyával készült, amelyhez az Arecaceae családhoz tartozó Phoenix dactylifera (L.) (datolyapálma) termését használták fel. A datolyapálma azonkívül, hogy flavonoidokban szintén gazdag, termése 70\%-ban tartalmaz szénhidrátokat, amely az árpa erjesztésénél, majd a megfelelő íz elérésénél kitüntetett szerepet játszik [4].

\section{Fenoloid típusú vegyületek és fitoszterolok}

Több komponensnél is jelentős hatóanyagcsoportot alkotnak a fotoszenzibilizáló kumarinszármazékok. Előfordulnak a már említett közönséges fügében, nílusi akáciában, valamint a Brassicaceal családhoz tartozó közönséges zsázsában (Lepidium Sativum L.) is. A füge fiatal hajtása, tejnedve fitofotodermatitist kiváltó lineáris furanokumarinokat tartalmaz - xantotoxol, bergaptén és pszoralén (ficusin) -, amelyek hatására a bőrre került növényi nedvek napfény jelenlétében súlyos bőrelváltozást okoznak. A fügében ezenkívül található még olyan természetes hidroxi-kumarin-származék, az umbelliferon, amely spasmolyticus hatású, vagy olyan furanokumarinok (5-metoxipszoralén és 8-metoxipszoralén), amelyek az Aedes aegypti szúnyog lárvájának a kifejlődését is képesek megakadályozni [29], ami által a májtüneteket is okozó sárgaláz megelőzhető, hiszen kórokozóját a szúnyog terjeszti.

A további hatóanyagokat tekintve a triterpén vegyületek számos képviselője gyakori komponense a receptek növényi összetevőinek. A fitoszterolok olyan szteránvázas vegyületek, amelyek csökkentik a vér koleszterinszintjét azáltal, hogy csökkentik a koleszterin felszívódását és növelik a máj LDL-receptor-expresszióját és az endogén koleszterint. A közönséges fügében és zsázsában jelentős sztigmaszterol, kampeszterol, illetve $\beta$-szitoszterol található. Hörcsögökön végzett kísérletek alapján azoknak a zsírmájas állatoknak az esetében, amelyek szárított fügét fogyasztottak, jelentősen csökkent a máj súlya, ellentétben a zsírdús diétát folytató hörcsögökkel. A nyolchetes kísérlet alatt folyamatosan ellenőrizték a vér HDL-, LDL-koleszterin-, triglicerid-, AST-, ALT-szintjét. A fügét fogyasztó hörcsögök esetében jelentősen javultak az előbb említett szérumparaméterek. A koleszterinszint csökkenésének egyik legmeghatározóbb oka a különböző fitoszterolok jelenléte a gyümölcsben [24] (3. ábra).

A receptek által említett másik leggyakoribb gyógyhatású komponens a Brassicaceal családhoz tartozó tömjén (Boswellia serrata L.), amelynek fóleg triterpén- és illó- 
olaj-tartalma járul hozzá a terápiás hatáshoz. A tömjént isteni szerként tartották számon, és az Óbirodalom korától elsősorban Puntból (valószínúleg a mai Szomália területén volt) exportálták Egyiptomba. Hatsepszut királynő (18. dinasztia) Deir el-Bahariban levő halotti templomában a növény honosításának kísérletét is megörökítették. A tömjénben található triterpének herpeszvírus-ellenes és immunmoduláns tulajdonsággal, a $\beta$-boswellinsav és származékai tumorellenes és antihyperlipidaemiás hatással rendelkeznek. A boswellinsav ezenkívül megvédi a májat a bakteriális endotoxin-mérgezéstôl, a fügéhez hasonlóan csökkenti a vér lipidszintjét, valamint antiarthritis és gyulladáscsökkentő hatású is. Ami pedig a hepatitis C-vírus elleni hatását illeti, egy korábbi tanulmány alapján elmondható, hogy a fertőzött betegek állapota jó eséllyel javulhatott. A krónikus HCVfertőzöttek körében mérsékli a májzsugor kialakulását, és gyakran javítja a betegek közérzetét [30].

A tömjén vizes kivonatokban csökkenti a teljes koleszterinszintet (38-48\%), és növeli a HDL-koleszterin-koncentrációt. A tömjénvizes kivonatokban és alkoholtartalmú gyógyszerekben is szerepelt édes sörrel vagy borral. Patkánykísérletek alapján a tömjén alkoholos kivonata gátolja a leukotrién B4 szintézisét peritonealis neutrophil granulocytákban, így csökkentve a gyulladást. A tömjén tehát más úton hat, mint egy NSAID hatástani csoportba tartozó gyógyszer, ezáltal kedvezóbb a mellékhatásprofilja is. Az alkoholos kivonat hepatoprotektív hatását egerekben is igazolták a galaktózamin/endotoxin által kiváltott májkárosodást követően. A kezelt egyedek szérum-ALT-, -AST-szintje csökkent [31].

\section{Szaponinok}

A szaponinok olyan triterpén vegyületek, amelyek szintén szignifikáns szerepet töltenek be számos növény terápiás hatásának kialakulásában. A szaponinokban gazdag növények gyulladáscsökkentő, expektoráns és tonizáló hatással rendelkeznek. A korábban említett közönséges fügében fóleg pentaciklusos triterpén szaponinok a jellemzőek (taraxaszterol és az oleanánvázas $\beta$-amirin), míg a sivatagi szilvában (Balanites aegyptiaca L., Zygophyllaceae) a szteroid szaponinok jelenléte a meghatározó. Az ókori egyiptomi gyógyászat is fóleg a tág értelemben vett hasi panaszok kezelésére használta, feltehetően hypoglykaemiás készítmények részeként, és a pnd-féreg kiûzésére (Eb79). A növényben található balanitin-7 és balanitin-6 rákellenes hatásúnak bizonyult. A gyümölcsból kivont balanitozid egy furosztán szteroid szaponin, amely tumorellenes hatását Ehrlich ascites carcinomában (EAC) szenvedő egereken is megvizsgálták. A balanitozidkezelés csökkentette az EAC-sejtek számát mind a profilaktikus, mind pedig a terápiás vizsgálatokban. A máj és a szérum MDA- (malondialdehid-) és NO(nitrogén-monoxid-) szintje csökkent, a CAT (kataláz) enzim szintje viszont növekedett a májban és a plazmában egyaránt. Az EAC-sejteket érintő kaszpáz-3-szint megnőtt [32]. Egy másik szteroid szaponinkomponens, a dioszgenin pedig napjainkban gyógyszeripari drog, szteroidhormonok szintéziséhez használatos. Ez a vegyület megváltoztatja a lipoxigenázaktivitást az erythroleukaemiás sejtekben, ezenkívül a megakaryocytákban bekövetkező morfológiai és biokémiai változásokért felelős. Egereken végzett kísérletek alapján a paracetamolkezelést követő gyógyszer-metabolizmus hatására bekövetkező súlyos májkárosodások részben megelőzhetők voltak. A növény kérgének vizes kivonata az AIDS és a leukaemia kezelésében is hatásosnak bizonyul. Molekuláris biológiai vizsgálatokkal bizonyítható volt, hogy az antiproliferatív profilnak köszönhetően az apoptotikus Bax gén és p53 gén expressziója fokozódik az MCF-7, HEPG-2 és HCT 116 sejtekben.

\section{Eb479 (67,11-13)}

Másik: lótuszlevél 1/8, bor 20 ro, krisztustövis lisztje 1/8, füge $1 / 8$, tej $1 / 16$, boróka $1 / 16$, tömjén 1/64, édes sör 20 ro, éjjel a harmatnak kitenni, összetörni, négy napig inni. (K.t: xA.w n sSn $1 / 8$, jrp 20, dqw n nbs $1 / 8$, dAb $1 / 8$, jrT.t $1 / 16$, pr.t n wan $1 / 16$, snTr $1 / 64$, Hnq.t nDm.t 20, sDr n jAd.t, atx, swj r hrw 4.)

A krisztustövis, Zizyphus spina-christi (Rhamnaceae) a közel-keleti és egyiptomi hagyományos gyógyászat közkedvelt eleme. A levelekkel történő meleg borogatást tályogok, furunkulusok kezelésére alkalmazták, valamint a friss levelekkel borogatták éjjel duzzadt szemeiket. Adsztringens hatása miatt szájvizek alkotója volt. A levelekben triterpén szaponinok, szaponin-glikozidok (krisztinin A, B, C, D), valamint flavonoidok (kvercetin, rutin, hiperozid) találhatók [33]. Az aflatoxinmérgezés által kiváltott májkárosodás hatékonyan kezelhető krisztustövis-kivonattal. Az aflatoxin-Bl-mérgezés patkányokon oxidatív stresszt idéz elő, amelynek következtében nő az ALT-, AST-, koleszterin-, triglicerid- és húgysavszint, valamint a TNF- $\alpha$-, illetve NO-szint. Egy tanulmányban a krisztustövis-kezelés hatására a biokémiai paraméterek és a szöveti elváltozások is jelentős mértékben javultak. A növényi kivonat gátolta a CYP $1 \mathrm{Al} / 2$ enzimet, amely részt vesz az aflatoxin-Bl bioaktiválásában. A kivonat az aflatoxin-Bl által okozott hepatocarcinogenesis és DNSkárosodás megakadályozását a fázis II enzimek, glutation-S-transzferáz és GSH-peroxidáz aktiválásával éri el [34].

\section{Illóolajok}

Néhány növényi komponens hatóanyagai közül az illóolaj-tartalom határozhatja meg döntően a terápiás hatást. A tömjén, a boróka (Juniperus phoenicea L.) és az ánizs (Pimpinella anisum L.) fóként illóolajdrogok, ennek megfelelően az emésztést javító és diuretikus hatásuk mellett a legjelentősebb az antimikrobás hatásuk. A tömjén gyógyhatású illóolaj-tartalmának számos komponensét sikerült azonosítani kapilláris GC/MS vizsgálatok alapján. Monoterpéneket $(13,1 \%)$, szeszkviter- 
péneket (1\%) és diterpéneket $(42,5 \%)$ tartalmaz. A Cupressaceae családba tartozó boróka tobozbogyó, a Juniperus communis L. termése. A legújabb kiadású $M a-$ gyar Gyógyszerkönyv is drogként tartja számon mind az áltermést, mind pedig a növényben található értékes illóolajat (Juniperi pseudofructus, Juniperi aetheroleum, $\mathrm{Ph}$. Hg. VIII.). Egyiptomban azonban a Juniperus phoenicea L. honos, és valószínúsíthető, hogy ennek a növénynek a különböző részeit használhatták drogként az óegyiptomi orvoslás korabeli képviselői. A GC/MS módszerrel meghatározott illóolaj-tartalom a levelekben és a tobozbogyóban fóként monoterpénekből áll. Biciklusos monoterpének a szabinén (tuján típus), $\alpha$-pinén, $\beta$-pinén (pinán típus), kámfor (kámfán típus), limonén, amely monociklusos monoterpén és mircén. Az illóolaj hatásosnak bizonyult agy-, tüdő-, máj-, illetve emlőcarcinoma-sejtvonalakon, valószínúleg a monoterpéneknek köszönhetően. A bogyóban található illóolaj-tartalom sokkal gazdagabb monoterpénekben, ezért nagyobb citotoxikus hatással bír májtumor esetén, mint a levélből nyert illóolaj [35]. Állatkísérletek bizonyítják, hogy a Juniperus phoenicea-kivonat, hasonlóan a szentjánoskenyérhez, hatásos a $\mathrm{CCl}_{4}$-dal mérgezett állatok terápiájában [36].

A Pimpinella anisum L. (Apiaceae) termése, az Anisi fructus a Ph. Hg. VII-ben is hivatalos drog. Már az ókori Egyiptomban is ismerték az ánizsban található illóolajkomponensek (anetol, izoanetol, ánizssav, ánizsketon, ánizsaldehid és dianetol) emésztést segítő, karminatív és simaizomgörcs-oldó hatását. A dianetol, amely állás közben transzanetolból dimerizációval képződik, ösztrogénhatással rendelkezik. A transzanetol pedig nagy dózisban májenzim-indukáló [37].

Eb481 (67,15-16)

Másik: füge $1 / 8$, felbasitott szikomorfüge $1 / 8$, borókabogyó $1 / 16$, felso"egyiptomi szia-ásvány $1 / 8$, viz 20 ro, éjjel a harmatnak kitenni, összetörni, négy napig inni.

(K.t: dAb l/8, nqAw.t l/8, pr.t wan l/16, sjA smAj.t 1/8, mw 20, sDr n jAd.t, atx, swj r hrw 4.)

Számos óegyiptomi receptben szerepel az a megfogalmazás, hogy „éjjel a harmatnak kitenni”, amelynek okát a korabeli receptek nem adják meg. Különböző okokra lehet gondolni, de a májra vonatkozó recepteknél feltételezzük, hogy a fogyasztás előtt az orvosság készítése során keletkezett mérgező gázok, például a cián eltávozását hivatott biztosítani. Ez az orvosi utasítás több, a nílusi akáciát tartalmazó receptben is megjelenik. Úgy tartják, hogy ez kiváló adsztringens, májtonizáló, lázcsillapító és asztmaellenes szer. Jelen korunkban is NyugatAfrikában a növény gumiszerú váladékát (mézga) és a fa kérgét tumorellenes szerként, valamint máj- és lépkárosodások leküzdésében használják a hagyományos gyógyászatban. A növény virágának, levelének és a mézgának citotoxikus és antimutagén hatását is leírták már [38]. A növényi kivonatok csersavat, szaponinokat, kumarinokat, triterpéneket, alkaloidokat, flavonoidokat, valamint cianogén vegyületeket is tartalmaznak [39]. Ez utóbbinak abban van jelentősége, hogy hidrolízise során HCN szabadul fel, amely halálos vegyületként ismeretes: citokróm-oxidáz enzimbénító. Nemcsak az akácia esetén, hanem a zsázsa használatánál is figyelembe kell venni a cianidtartalmú illó komponensek meglétét. Mindkét növény említésénél szerepel a gyógyszer fogyasztása előtti pihentetésre vonatkozó előírás.

A közönséges zsázsa (Lepidium Sativum L.) a Brassicaceae családba tartozó, az óegyiptomi gyógyászatban gyakran használt növény. A herba fitoszterolokban ( $\beta$-szitoszterol) bővelkedik, amelyet köhögéscsillapítás és aranyeres vérzés esetén használtak. A recept alapján azonban valószínűsíthető́n a zsázsa leveleit használták, amelyek vitaminokban (tiamin, riboflavin, niacin, aszkorbinsav) és illó mustárolajokban (benzil-cianid, benzil-izotiocianát) gazdagok. A levélkivonatok diuretikumok, a későbbi népgyógyászatban a gyökeret pedig szekunder szifilisz esetén használták. A zsázsában található benzil-izotiocianát csökkentette a kinolin okozta DNS-károsodást vastagbél- és májsejtekben. A zsázsa májvédő hatását szintén igazolták $\mathrm{CCl}_{4}$-mérgezést követően, patkányokon $[40,41]$.

Hasonlóan jó eredményeket kaptak a földitök (Bryonia alba L.) és a közönséges nád (Phragmites australis L.) esetében is [42]. A Cucurbitaceae családba tartozó földitök Európa, Észak-Afrika és Dél-Ázsia egyes területein őshonos. A benne található kukurbitacinok (triterpének és azok glikozidjai) citotoxikusak, amelynek tünetei a fájdalom, a súlyos kiszáradással járó hányás és hasmenés. Ma leginkább a homeopátiás készítmények tartalmazzák ízületi gyulladás, fejfájás, bronchitis és pneumonia kezelésének céljából [43]. A földitök hepatoprotektív hatását $\mathrm{CCl}_{4}$ által károsodott hepatocyták sikeres regenerációja és a sejtek membránja integritásának megơrzése bizonyítja. A tradicionális gyógyászatban a növény gyökerét köhögés, peritonitis, a savós szövetek gyulladása, tüdőgyulladás, reuma, sárgaság és tífusz kezelésére használják [44].

\section{$\operatorname{Eb478~(67,9-11)~}$}

Másik: füge $1 / 8$, mazsola $1 / 8$, peret-seni $1 / 16$, nád $1 / 16$, tömjén 1/64, okker (stj) 1/32, viz 1/32, ugyannigy.

(K.t: dAb 1/8, wnSj 1/8, pr.t Snj 1/64, jsw 1/16, $\operatorname{sn} \operatorname{Tr} 1 / 64, \operatorname{stj} 1 / 32, \mathrm{mw} \mathrm{l} / 32$, mjt.t.)

A Poaceae családba tartozó közönséges nád rhizomájának májvédő tulajdonságai hozzájárulhatnak az idült hepatitisfertőzés során kialakult májfibrosis, -cirrhosis és hepatocellularis carcinoma kezeléséhez, amelyet érdekes módon az ősi kínai medicina szintén használt. A növény levelét leginkább bronchitis és kolera kezelésére használták az egyiptomi népi gyógyászatban [45].

A receptek további összetevői a lótuszlevél, a vas(III)oxid tartalmú okker, illetve a tej. A lótuszlevél ( Nymphaea lotus, Nymphaea cerula, Nymphaeaceae) hepatoprotektív tulajdonságait még nem mutatták ki, azonban a benne található apomorfin felelős lehet az opioidokra 


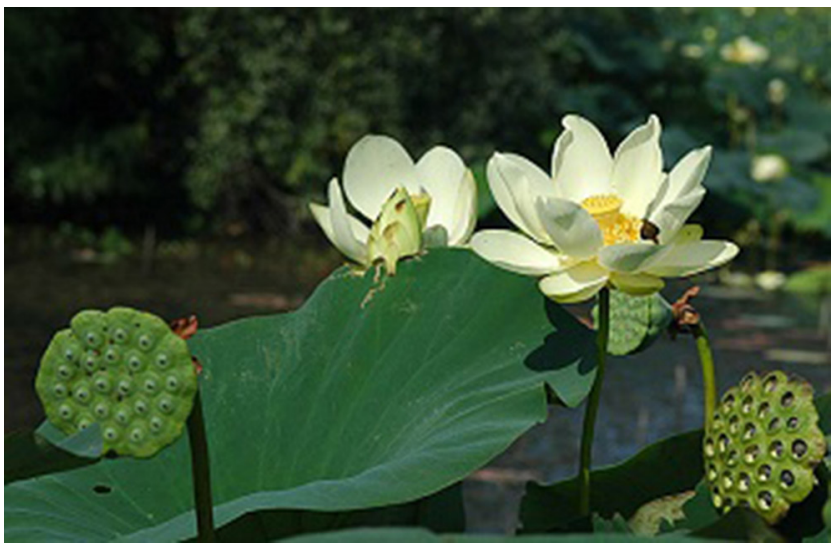

4. ábra | Lótuszvirág képe termésével

jellemző hatások kiváltásáért. Többek között fájdalomcsillapító, euforizáló, emetikus és obstipans hatású. Figyelemre méltó, hogy az ókori egyiptomiak mellett a maja kultúra is felismerte a növényi kivonat hallucinogén és emetikus hatását, amely a gyógyító, illetve „tisztító” rituálék igen fontos részét képezte [46] (4. ábra). Az okker ásványi festékanyagot, főként adsztringens és antiszeptikus tulajdonságai miatt, külsőleg bőrfertőzések kezelésére használták [47]. A receptekben említett tej főleg vivőanyagként szerepelhetett. Azon kívül, hogy fontos tápanyagokat és ásványi anyagokat tartalmaz, immunmoduláns és szabadgyök-fogó hatással is rendelkezik [4].

Szerzői munkamegosztás: K. J.: Farmakognóziai kutatások, receptek gyógyszerészi értelmezése. Gy. H.: Kortörténeti vonatkozások, az egyiptomi receptek fordítása. B. A.: Orvosbiokémiai értelmezések, szerkesztési feladatok.

\section{Következtetés}

Az említett és részletesen feldolgozott orvosi receptek, amelyek az óegyiptomi társadalmat érintő májkárosodások megfelelő tradicionális módszerekkel történő kezelését célozták meg, nagy segítséget jelenthetnek abban, hogy jobban megértsük a korabeli gyógymódok hatásosságát, és új lehetőségeket vessenek fel a kutatás számára, kiszélesítve a modern gyógyászat területének a határait.

\section{Irodalom}

[1] McMichael, A. J., Campbell-Lendrum, D. H., Corvalán, C. F., et al.: Climate change and human health. Risks and responses. WHO, Geneva, 2003. Available from: http://www.who.int/ globalchange/climate/summary/en/index5.html

[2] Neal, P. M.: Schistosomiasis - an unusual cause of ureteral obstruction. A case history and perspective. Clin. Med. Res., 2004, 2(4), 216-227

[3] Mohamoud, Y. A., Mumtaz, G. R., Riome, S., et al.: The epidemiology of hepatitis $C$ virus in Egypt: a systematic review and data synthesis. BMC Infect. Dis., 2013, 13, 288. DOI: 10.1186/1471 2334-13-288.

[4] Katona, J., Györy, H., Blázovics, A.: Removal of weremit from the abdomen. Interpretation and efficacy of an ancient Egyptian prescription by the newest scientific results. [A weremit kiüzése a hasból. Óegyiptomi recept hatásosságának értelmezése az újabb kutatási eredmények alapján.] Orv. Hetil., 2015, 156(50), 20452051. [Hungarian]

[5] Sandison, A. T., Tapp, E.: Disease in ancient Egypt. In: Cockburn, A., Cockburn, E., Reyman, T. A. (eds.): Mummies, disease and ancient cultures. Cambridge University Press, Cambridge, $\mathrm{UK}, 1998,35$.

[6] Györy, H.: "Live for 110 years on earth, and your membes stay strong." Way of life and health in ancient Egypt. [„Tölts be száztíz évet a földön és tagjaid maradjanak erősek." Életmód és egészség az ókori Egyiptomban.] Kriterion, Kolozsvár, 2003, 70-72, 91-93, 99-102, 154-155. [Hungarian]

[7] WHO Statistics, 2015. Available from: http://www.who.int/ countries/egy/en/

[8] David, A. R., Kershaw, A., Heagerty, A.: Atherosclerosis and diet in ancient Egypt. The Lancet, 2010, 375(9716), 718-719.

[9] Blázovics, A., Györy, H., Fehér, J.: Medicine in ancient Egypt. [Orvoslás az ősi Egyiptomban.] Orv. Hetil., 1999, 140(26), 1471-1475. [Hungarian]

[10] Grapow, H.: Grundriss der Medizin der alten Ägypter, II. Berlin, $1955,92,95$.

[11] Grapow. H.: Grundriss der Medizin der alten Ägypter, III. Berlin, $1956,32$.

[12] Westendorf, W.: Papyrus Edwin Smith, ein medizinisches Lehrbuch aus dem alten Ägypten. H. Huber, Bern-Stuttgart, 1966, p. 927.

[13] Györy, H.: Medicina theoretica Aegyptiorum. Orvostört. Közl., Budapest, 2002, 178-181, 45-73.

[14] Edwards, I. E.: Oracular amuletic decrees of the late New Kingdom. Hieratic Papyri in the British Museum, 4th Series. London, 1960, T. 1. Rs. 93

[15] Györy, H.: "The liver has four vessels." Anatomical knowledge about the liver in the Ebers papyrus. [„Négy ere van a májnak.” A májról alkotott anatómiai ismeretek az Ebers papiruszban.] Orv. Hetil., 2001, 142(20), 1061-1066. [Hungarian]

[16] Györy, H.: Interaction of magic and science in Ancient Egyptian Medicine. In: Hawass, Z. (ed.): Egyptology at the Dawn of the Twenty-first Century. Proceedings of the Eighth International Congress of Egyptologists, Cairo 2000, AUC Press, Cairo, 2002, 276-283.

[17] Györy, H.: Drug-making procedures in ancient Egypt. Part 1. [Gyógyszerkészítési eljárások az ókori Egyiptomban. 1. rész.] Magyar Orvosi Nyelv, 2011, 9(1), 14-21. [Hungarian]

[18] Manniche, L.: An ancient Egyptian herbal. British Muzeum Publications, London, 1989. Germer, R.: Die Heilpflanzen der Ägypter. Artemis und Winkler, Düsseldorf-Zürich, 2002.

[19] Koriem, K. M., Farrag, A. R. H., Badawy, M. A., et al.: Role of some Egyptian medicinal plants against liver and kidney toxicity induced by cadmium chloride. Toxicol. Mech. Methods, 2009, $19(8), 524-534$.

[20] Mawa, S., Husain, K., Jantan, I.: Ficus carica L. (Moraceae): Phytochemistry, traditional uses and biological activities. Evid. Based Complement. Altern. Med., 2013, 2013, ID 974256.

[21] Joseph, B., Raj, S. J.: Pharmacognostic and phytochemical properties of Ficus carica Linn - An overview. Int. J. Pharm Tech. Res., 2011, 3(1), 8-12.

[22] Balázs, A., Ficsor, E., Györy H.: The history of the fig tree (Ficus carica $\mathrm{L}$.) and its use in phytotherapy. [A fügefa (Ficus carica L.) története és fitoterápiás alkalmazása.] Orv. Hetil., 2011, 152(2), 72-75. [Hungarian]

[23] Lazreg Aref, H., Gaaliche, B., Fekih, A., et al.: In vitro cytotoxic and antiviral activities of Ficus carica latex extracts. Nat. Prod. Res., 2011, 25(3), 310-319. 
[24] Tawfik, M. S., Alhejy, M.: Antioxidants in fig (Ficus carica L.) and their effects in the prevention of atherosclerosis in hamsters. J. Food Nutr. Sci., 2014, 2(4), 138-145.

[25] El-Sayed, M. M., Abdel-Hadi, A. M., Sabra, A. N., et al.: Effect of Ficus sycomorus and Azadirachta indica extracts on liver state of mice infected with Schistosoma mansoni. J. Egypt. Soc. Parasitol., $2011,41(1), 77-88$.

[26] Onyishi, I. V., Chime, S. A., Okeke, C.: Evaluation of the antioxidant properties of Vitis vinifera juice extract in rifampicin dispersions. Afr. J. Pharm. Pharmacol., 2013, 7(24), 1619-1624.

[27] Ahmed, M. M.: Biochemical studies on nephroprotective effect of carob (Ceratonia siliqua L.) growing in Egypt. Nature and Science, 2010, 8(3), 41-47.

[28] Ibrabim, A. H., El-Baky, R. M., Desoukey, S. Ү., et al.: Bacterial growth inhibitory effect of Ceratonia siliqua L. plant extracts alone and in combination with some antimicrobial agents. J. Adv. Biotechnol. Bioeng., 2013, 1(1), 3-13.

[29] Chung, I. M., Kim, S. J., Yeo, M. A.: Immunotoxicity activity of natural furocoumarins from milky sap of Ficus carica L. against Aedes aegypti L. Immunopharmacol. Immunotoxicol., 2011, 33(3), 515-518.

[30] Badria, F. A.: Frankincense (Heaven's Gift) - Chemistry, biology, and clinical applications. In: Badria, F. A. (ed.): Evidencebased strategies in herbal medicine, psychiatric disorders and emergency medicine. InTech, Rijeka, 2015.

[31] Upaganlawar, A., Ghule, B.: Pharmacological activities of Boswellia serrata Roxb. Ethnobotanical Leaflets, 2009, 13, 766774 .

[32] Zaabkouk, S. A., Aboul-Ela, E. I., Ramadan, M. A., et al.: Anti carcinogenic activity of methanolic extract of Balanites aegyptiaca against breast, colon, and liver cancer cells. Int. J. Adv. Res., 2015, 3(6), 255-266.

[33] Shabat, A. A., Pieters, L., Apers, S., et al.: Chemical and biological investigations on Zizyphus spina-christi L. Phytother. Res., 2001, 15(7), 593-597.

[34] Abdel-Wahbab, M. A., Omara, E. A., Abdel-Galil, M. M., et al.: Zizyphus spina-christi extract protects against aflatoxin $\mathrm{B}_{1}$-initiated hepatic carcinogenicity. Afr. J. Tradit. Complement. Altern. Med., 2007, 4(3), 248-256.

[35] El-Sawi, S. A., Motawae, H. M., Ali, A. M.: Chemical composition, cytotoxic activity and antimicrobial activity of essential oils of leaves and berries of Juniperus phoenicea grown in Egypt. Afr. J. Tradit. Complement. Altern. Med., 2007, 4(4), 417-426.
[36] Ali, S. A., Rizk, M. Z., Ibrabim, N. A.: Protective role of Juniperus phoenicea and Cupressus sempervirens against $\mathrm{CCl}_{4}$. World Gastrointest. Pharmacol. Ther., 2010, 1(6), 123-131.

[37] Shojaii, A., Abdollahi Fard, M.: Review of pharmacological properties and chemical constituents of Pimpinella anisum. ISRN Pharm., 2012, 2012, ID 510795. DOI: 10.5402/2012/510795

[38] Ali, A., Akbtar, N., Khan, B. A.: Acacia nilotica: A plant of multipurpose medicinal uses. J. Med. Plants Res., 2012, 6(9), 14921496.

[39] Abd El-Aziz, A. M., Awad, N. E., Seida, A. A., et al.: Biological and chemical evaluation of the use of Acacia nilotica (L.) in the Egyptian traditional medicine. Int. Bull. Drug Res., 2013, 3(5), 1-19.

[40] Manohar, D., Viswanatha, L. G., Nagesh, S., et al.: Ethnopharmacology of Lepidium Sativum Linn (Brassicaceae): A Review. Int. J. Phytother. Res., 2012, 2(1), 1-7.

[41] Wadhwa, S., Panwar, M. S., Agrawal, A., et al.: A review on pharmacognostical study of Lepidium Sativum. Adv. Res. Pharm. Biol., 2012, 2(4), 316-323.

[42] Chen, S., Ju, M., Luo, Ү., et al.: Hepatoprotective and antioxidant activities of the aqueous extract from the rhizome of Phragmites australis. Z. Naturforsch C., 2013, 68(11-12), 439-444.

[43] Joshi, V., Joshi, R. P.: Some plants used in ayurvedic and homeopathic medicine. J. Pharmacog. Phytochem., 2013, 2(1), 269275.

[44] Manvi, G. G.: Evaluation of pharmacognostical parameters and hepatoprotective activity in Bryonia alba Linn. J. Chem. Pharm. Res., 2011, 3(6), 99-109.

[45] Mabmoud, T., Gairola, S.: Traditional knowledge and use of medicinal plants in the Eastern Desert of Egypt: a case study from Wadi El-Gemal National Park. J. Med. Plants Stud., 2013, 1(6), $10-17$.

[46] Meyer, G. G., Kenneth Blum, M. D., Cull, J. G., et al.: Folk medicine and herbal healing. Springfield, Illinois, U.S.A., 1976.

[47] Leake, C. D.: The old Egyptian medical papyri. Logan Clendening lectures on the history and philosophy of medicine, 2nd series. University of Kansas Press, Lawrence, Kansas, 1952.

(Blázovics Anna dr., Budapest, Üllői út 26., 1085 e-mail: blazovics.anna@pharma.semmelweis-univ.hu)

Az Orvosi Hetilap egyes számai megvásárolhatók a Mediprint Orvosi Könyvesboltban. Cím: Budapest V., Múzeum krt. 17. - Telefon: 317-4948 